\title{
THE MANAGEMENT OF INTERNATIONAL COOPERATION IN SEBELAS MARET UNIVERSITY IN THE PERSPECTIVE OF GOOD UNIVERSITY GOVERNANCE
}

\author{
Anies Fortina Febriani \\ Magister of Public Administration, Sebelas Maret University \\ Email: anies14a@yahoo.com
}

DOI: https://doi.org/10.18196/jgpp.5192

Article Info

Article history:

Received 18 Jan 2018

Revised 15 Feb 2018

Accepted 15 Mar 2018

Keywords:

management,

international

cooperation, Good

University Governance

\section{ABSTRACT}

Objectives of this study are (1) to know the description of the management of international partnership in Sebelas Maret University (UNS) from the perspective of Good University Governance (2) to identify factors that affect the management of international partnership at the Sebelas Maret University.

The location of this study conducted at the Sebelas Maret University. Type of the research is qualitative descriptive. Sources of data obtained from sources person, places and events or activity that was observed, and also from documents. The sampling technique of this study is purposive sampling. The data collection technique is by interview, observation and document review. Triangulation techniques was used to ensure the validity of the data.

From the study of management of international partnership at the Sebelas Maret University shows several results (1) The principle of transparency has been accomplished on the mechanism that facilitates the public questions about the processes in governance but not in the application of the system of openness and the clearness and easiness to understand standardization all the processes of governance, and the mechanism for reporting and dissemination of information about aberrations action; (2) The principle of accountability has been accomplished in the distribution and grouping of work in accordance with the duties and functions principally but not in the understanding of the duties and functions as a manager and executor of cooperation, and accountability mechanisms of the budget; (3) The principle of responsibility is not yet implemented in the management of international cooperation; (4) the factors that support the implementation of Good University Governance are human resources and authority, while the inhibiting factor are the organizational structure and coordination systems

\section{ABSTRAK}

Tujuan dari penelitian ini adalah (1) mengetahui gambaran pengelolaan kemitraan internasional di Universitas Sebelas Maret (UNS) dari perspektif Good University Governance (2) untuk mengetahui faktor-faktor yang mempengaruhi pengelolaan kemitraan internasional di Universitas Sebelas Maret. . 
Lokasi penelitian ini dilakukan di Universitas Sebelas Maret. Jenis penelitiannya adalah deskriptif kualitatif. Sumber data diperoleh dari sumber orang, tempat dan kejadian atau aktivitas yang diamati, dan juga dari dokumen. Teknik pengambilan sampel dalam penelitian in adalah purposive sampling. Teknik pengumpulan datanya adalah dengan wawancara, observasi dan review dokumen. Teknik triangulasi digunakan untuk memastikan keabsahan data.

Dari studi pengelolaan kemitraan internasional di Universitas Sebelas Maret menunjukkan beberapa hasil (1) Prinsip transparansi telah dicapai pada mekanisme yang memfasilitasi pertanyaan publik tentang proses dalam pemerintahan namun tidak dalam penerapan sistem keterbukaan dan kejelasan dan kemudahan untuk memahami standarisasi semua proses pemerintahan, dan mekanisme pelaporan dan diseminasi informasi tentang tindakan penyimpangan; (2) Prinsip pertanggungjawaban telah dilakukan dalam pendistribusian dan pengelompokkan pekerjaan sesuai dengan tugas dan fungsinya pada prinsipnya namun tidak dalam pengertian tugas dan fungsi sebagai manajer dan pelaksana kerja sama, dan mekanisme pertanggungjawaban anggaran; (3) Prinsip tanggung jawab belum diimplementasikan dalam pengelolaan kerjasama internasional; (4) faktor-faktor yang mendukung pelaksanaan Good University Governance adalah sumber daya manusia dan otoritas, sedangkan faktor penghambatnya adalah struktur organisasi dan sistem koordinasi.

\section{INTRODUCTION}

Responsibility in presenting quality education is a major focus in the world of higher education. Universities as a unit of the current highest education providers carry heavier task in line with global demands to produce qualified and high performance human resources. According to Suharsaputra (2015:11):

"At least there are challenges for higher education that are important to be observed and addressed by each college with precise and intelligent at the same quick wit: (1) the level of competition is higher, both inter College (Organizer of Higher Education) in the country (local, regional, national) as well as with foreign countries; (2) The escalation of the 
development of science and technology communication and information very quickly and varied, both the depth and comprehensiveness; (3) Strengthening of community life based on knowledge (knowledge society); (4) Strengthening of supervision by the public and the government; (5) the increased demand for educational outcomes (outputs of education and also education outcomes) quality; (6) the increased demand for competencies and the pursuit of the relevant higher education graduates (outcomes of education); (7) Increased demand for the implementation of qualified higher education with certain standards."

Ministry of Research, Technology and Higher Education has established high achievement standard for the whole universities that is World Class University (WCU) policy. Hendarman, Director of Directorate of Institutional, Director General of Higher Education stated in WCU includes 1) World Reputation 2) Research Performance 3) Prominent Graduates 4) International Participation. Purbani quoted Albatch (2003) that WCU is a university that enter in the main ranking universities in the world because it has the excellence world standards.

To be able to manifest itself into a World Class University College requires the support of a network of wide open cooperation with the international as mentioned in the fourth element of the WCU, the International Participation in the form of participation in the international arena that have been followed.

The demands of realizing WCU was warmly welcomed by the Sebelas Maret University through the Higher Education internationalization program by activating various kinds of cooperation with various parties such as higher education institutions, industry, donors and partners abroad. It is expected that with the cooperation with various parties abroad it will form a network that is able to lift the name of UNS in the international community.

In line with the UNS has also formulated Targets Phase I (20112015) as the stages of development: Autonomy and Independence 
62 Acceleration UNS priority programs which lead to the development of the system of management towards the realization of Good University Governance (GUG); increase the autonomy and independence of universities; and organizing Tridarma towards international reputable universities.

Thus efforts in developing international cooperation management which refers to the principles of GUG as the ideal form of management of higher education system in Indonesia is a serious attempt of Sebelas Maret University in managing international cooperation. With the hope that with the of management international cooperation based on Good University Governance can improve both the quantity and quality of international cooperation, expand the network and make a significant contribution in supporting the autonomy and independence of university as well as the achievement of the three responsibilities of Higher Education .

In Sebelas Maret University the management of cooperation with external parties in the period $2008-2015$ is handled by the Public Relations and Cooperation Office. The scope of cooperation UNS as set out in the Rector Decree No. 1 / H27 / KL / 2008 dated January 3, 2008 on Guidelines for Cooperation of the Sebelas Maret University are the areas which include the provision of education, student development, implementation of research and laboratories, and the implementation of community service, both in the scope of activities undertaken in cooperation with agencies/ institutions internal and external university. While the stage in the cooperation activities carried out by implementing cooperation within the Sebelas Maret University include planning, implementation, monitoring, and evaluation and follow-up with the Office of Public Relations and Cooperation UNS as implementing units assigned to coordinate and administer or run a co-operative activities on conducting a universitylevel adviser under Vice Rector whom responsible to the Rector. But with the Regulation of the Minister of Education and Culture of the 
Republic of Indonesia Number 82 of 2014 dated August 20, 2014 on the Organization and Work Procedure (OTK) Sebelas Maret University, then as stated in article 20 of this regulation the Legal and Administrative Cooperation Division which then performs functions coordination the implementation of cooperation programs domestically and the implementation of the administrative cooperation activities in domestic and overseas.

Table 1

The Number of Cooperation Carried by UNS Domestic and

Overseas

\begin{tabular}{cccccc}
\hline Year & $\begin{array}{c}\text { Numb } \\
\text { er of } \\
\text { Coope } \\
\text { ra } \\
\text { tions }\end{array}$ & $\begin{array}{c}\text { Domesti } \\
\mathbf{c} \\
\text { Coopera } \\
\text { tions }\end{array}$ & $\begin{array}{c}\text { Oversea } \\
\mathbf{s} \\
\text { Coopera } \\
\text { tions }\end{array}$ & $\begin{array}{c}\text { Cooperation } \\
\text { s Run until } \\
\mathbf{2 0 1 5}\end{array}$ & $\begin{array}{c}\text { Cooperation } \\
\text { s Ended until } \\
\mathbf{2 0 1 5}\end{array}$ \\
\hline 2006 & 66 & 55 & 11 & 11 & 55 \\
\hline 2007 & 39 & 30 & 9 & 15 & 24 \\
\hline 2008 & 45 & 42 & 3 & 16 & 29 \\
\hline 2009 & 32 & 32 & 0 & 9 & 23 \\
\hline 2010 & 87 & 79 & 8 & 22 & 65 \\
\hline 2011 & 118 & 97 & 21 & 55 & 63 \\
\hline 2012 & 117 & 93 & 24 & 59 & 58 \\
\hline 2013 & 139 & 127 & 12 & 70 & 69 \\
\hline 2014 & 59 & 56 & 46 & 72 & 24 \\
\hline 2015 & 102 & 53 & 49 & 103 & 14 \\
\hline \multicolumn{5}{c}{ Source: Legal and Administrative Cooperation Division Sebelas } \\
Maret University & & &
\end{tabular}

The target of institutional indicators that is international cooperation is 58 international cooperations in 2014, that is becoming Key Performance Indicators (KPI) in the end of 2019 listed in the Business Strategic Plan UNS 2015-2019 as the benchmark of achievement target 2015-2019 can not be reached as the UNS international cooperations number in 2014 is only 46 . 
6. Role of international cooperation can not be under estimated in the achievement of World Class University, that is why it is necessary to observe and analyze how is actually the management of international cooperation in UNS and also to elaborate factors that influence the development and increase of number and quality cooperation in UNS.

Some evidence suggests that the management of cooperation in Sebelas Maret University should immediately get improvements. First, in terms of management cooperation requires a legal product in the form of rules and standard operating procedure (SOP) standard which is currently not owned by UNS. Up to 2015 there has been no standard SOP on the working procedures of cooperation at both domestic and overseas. Second, UNS internationalization program budget management and utilization of income funds from cooperations have a mechanism that convoluted and lead to budget users encountered many difficulties in the disbursement and accountability use. As stated by the team members of internationalization of the Faculty of Social and Political Sciences UNS:

"We are required to implement the initiation of overseas cooperation as much as possible but for disbursement and accountability of the funds are very difficult. And what is surprising is the management of budgets between one to another faculties at UNS why be different? That's what makes us think twice when going to carry out international activities."

The third findings is that some agreements and cooperations contracts existing in the UNS there are carried out by individuals directly (personally) with a second party outside the UNS, is still using UNS name for the legalization. While such agreement and contract to be able to recognize should receive legalization or validation from UNS and should be able to contribute to the institution . 
The fourth, until now there has been no maintenance system for Memorandum of Understansing (MoU) and Memorandum of Agreement (MoA). As the result, only small amount of $\mathrm{MoU}$ and MoA owned by UNS are properly registered and recorded on the cooperation database in the Legal and Administrative Cooperation Division. There are still difficulties to extend $\mathrm{MoU}$ that is already expired because there is no person in charge or contact person from each of the parties.

\section{LITERATURE REVIEW AND RESEARCH FOCUS}

\section{Cooperation}

In the terminology of public administration, cooperation becomes an indispensable element. For the administration broadly meaning is the whole process of cooperation between two or more people in achieving goals by utilizing certain infrastructure efficiently and effectively. Tangkilisan (2005:86) also suggests that,

"the external and internal environment, ie all forces that arise beyond organizational boundaries can influence decisions and actions within the organization. Therefore there should be cooperation with the expected strength may arise. Such cooperation may be based on rights, obligations and responsibilities of each person to achieve the goal."

According to Pamudji (1985:12-13), not every relationship can be categorized as a cooperation. As on his statement:

"Cooperation is essentially indicate two or more parties that interact dynamically to achieve a common goal. In that sense it contained three main elements attached to a framework of cooperation, which is an element of two or more parties, the interaction elements and elements of a common goal. If one of these elements not contained in the object under study, it can be considered that cooperation was not found in the object. Elements of the two parties, which always describe a set of mutually influence each other so that interaction to achieve common goals is important. If the relationship or interaction was not aimed at the 
fulfillment of the interests of each party, the relationship is not a partnership. An interaction considered as dynamic though, does not always mean cooperation. An interaction which is intended to meet the interests of other parties involved in the process of interaction, nor a partnership. Cooperation always putting the parties interact on an equal footing, and in harmony."

Bowo and Andy (2007 : 50-51) said that in the implementation of the cooperation should be achieved mutual benefit for all parties involved (win win). If there is one aggrieved party in the process of cooperation it can be said that collaboration is no longer met. In an effort to achieve profits or the mutual benefits of cooperation, good communication and understanding between all parties together toward a common goal are required.

Cooperation exists because of the emergence of dependency which drives to the awareness of each party that basically they do not fully have the resources to solve problems. The consideration that these resources may be owned only by the other party. Through cooperation allows two or more parties have the opportunity to achieve common goals in the condition of the two or more parties have the same position or equivalent in carrying out their respective roles. The success in the implementation of the cooperation should be based on the general principles as described by Edralin and Whitaker in Keban (2007:35), namely : transparency, accountability, participatory, efficiency, effectiveness, consensus, mutual benefit and advance. With compliance on these principles it is expected that beneficial outputs and outcomes for both parties can be achieved.

\section{Higher Education Cooperation}

Higher education cooperation as embodied in the Regulation of the Minister of Education and Culture No. 14 of 2014 on Higher Education Cooperation, is an agreement between universities in 
Indonesia with universities, businesses, or other parties, both domestics and abroad.

Cooperation undertaken with the business world is one form of cooperation that is considered to give positive effect both in the academic and material. As stated by Breen and Hing (2001:57)

"Benefits for both partners are espoused on the cooperative education partnerships between industries and universities.

It was found that benefits for industry comprised enhanced industry profesionalism and legitimacy; increased professional status; better public image; control of abstract knowledge and improved industry competitiveness. For the university, key benefits have included improved educational offerings; enhanced university reputation in the discipline and for cooperative education partnerships; additional students fees and economies of scale; and funds for discipline development and research and consultancy opportunities."

In the world of higher education cooperation has a very big role in achieving the vision and mission as well as the development of Tri Dharma (education, research and development, community service), because through cooperation it will be created mutually beneficial relationship and learning and knowledge exchange that will experienced by each of the parties that cooperates.

"One method to increased research and scholarly collaborative activity is through the use of cooperative interactions between faculty from different schools or colleges. This collaboration can be regional, national or international." (Gallicchio, 2007: 207)

The development of cooperation as one of the priority programs in the Business Strategy Plan of University is a crucial thing. Cooperation of university with other universities, businesses, and / or other party at a later stage will lead to the creation of a network where the network will greatly influence the improvement of 
68 company imaging and marketing, which in turn will help the university to survive and compete in the global market.

\section{Higher Education Internationalization}

The obligation of the university has stated in Law No. 20 of 2003 that the university is obliged to provide education, research and community service. And it is again mentioned in Law No. 12 of 2012 that the three responsibilities of Higher Education, hereinafter referred Tridharma is the duty of the universities to provide education, research, and community service. Viewed in that context Suharsaputra (2015:225) argues that the quality of higher education will describe how the implementation quality of its Tridharma.

Meaning of internationalization as in the report of the Government of Japan in the Council for the Asian Gateway Initiative quoted by Yonezawa, Akiba and Hirouchi (2013:17)

However, it should be noted that university internationalisation is a multi-layered concept consisting of such diverse ideas as enhancing international exchanges of students and faculty members, making the campus a multilingual and multinational community, providing double degree programs, conducting and participating in international joint research projects, establishing and operating overseas offices, and improving international recognition and reputation. Therefore, internationalisation is not something that all universities should pursue in unison, but something that each university should address voluntarily, based on its characteristics.

Internationalization of education interpreted by Suharsaputra (2015:6) as a way of managing education by developing cooperation among countries as an important part of the education building. Another definition of the internationalization as stated by Satoto E Nayono in (2012): 
"The internationalization of higher education is defined as a process in higher education that integrates international components into purpose, functions or delivery of education (including curriculum development and innovation; exchange of lecturers and students, the development and expansion of the program of study; utilization of technological assistance for learning, cultural training, education for international students, and research/publications together)."

Internationalization of higher education is not just providing a predicate international to a university because of its reputation but rather the integration of universal values into the system of education management and mutual understanding of culture in the form of a cooperative relationship with the international community to realize the management of education which is internationally qualified, without having to remove any characteristics elements of university culture of origin itself .

\section{Good University Governance}

In education there are higher education management (academic) and schools. Administration management in academic is the process of all administrative performing activities relating to the areas of education in which involves the cooperation of all the personal and the synergy of performance in accordance with the duties and position in order to achieve a predetermined goal. The concept of academic administration consists of various sub-systems interconnected with each other to achieve goals.

"Educational administration have in common purpose, namely the attempt to integrate sources unrelated into total system directed towards achieving the goal. The source is the people, tools, media materials, funds, infrastructure and other facilities." (Herabudin, 2009:148).

Management or good governance can provide the conditions where learning and research can thrive. The emphasis that the success 
of a university is determined by the student is not entirely acceptable because when we reviewed all elements were contributing: learning a good, reliable research, academic excellence service, atmosphere conducive learning, academic and social environments that are managed. It brought the positive impact on the learning experience of a good and effective education. Even in the long term can contribute in the form of affection and loyalty of students to his almamater.

"Thus, the university management is a holistic process, the function of the whole unit is working very closely linked and interdependent. The impact is that the weakness of the function can affect the other, and the strength of the functions can reinforce the other. "( Aseri , 2015)

In 1999 , the National Committee on Corporate Governance has issued a Code of Good Corporate Governance ( GCG ) and first amended in 2001. The principle of good corporate governance, namely: transparency, independence, accountability, responsibility, equality and fairness. In a Public Service Board performance-based organization management can only be done if the organization is carried out on the basis of the principles of governance that ensures the implementation of good practices (good practices) therefore then principles of good corporate governance was adopted into the management of the university .

The principles of Good University Governance that will be used to analyze on this study are the principles of Transparancy, Accountability and Responsibillity. Since there are synergistic connection between Muhi's (2010) principles of Good University Governance with the general principles of success in the implementation of cooperation by Edralin and Whitaker (Keban, 2007), and also principles of Good University Governance that are disseminated by the Directorate of Institutional and Cooperation Directorate General of Higher Kemdikbud. The three principle of the 
Good University Governance also has a relevant connection with Sasaran Tahap I (2011-2015) which is continued into the Sebelas Maret University Business Strategy Plan.

Definition of 'transparency' in the field of bureaucracy interpreted by some experts as follows, Mardiasmo (2002) states that transparency means openness of government in providing information related to the activity of management of public resources to those who need the information. Krina P (2003), transparency interpreted as a principle that guarantees access or the freedom for everyone to obtain information about government administration, information on policies, the process of making and implementation and the results achieved. Dwiyanto (2006) defines transparency as providing information on public administration and guaranteed the ease of obtaining information that is accurate and adequate.

Mardiasmo (2002) explains that accountability is an obligation to report and take responsibility for the success or failure of the mission of the organization in achieving predefined results through media accountability which is done regularly. Accountability is the ability to give an answer to a higher authority for the actions of a person / group of people to the wider community within an organization (Rasul, 2002).

Sudarmo (2011) points out that,

"Responsibility related to the principle that in serving stakeholders, administrators must adhere to the values of the administration and the policies that have been taken by the policy makers. The values of the administration and the policy can be put explicitly or implicitly as the legal basis for acting administrator, perform the duties and must comply with them."

\section{Management of University International Cooperation}

Governance is often referred to or equated with management. Administrative management is the management of all the interests institutionally administrative nature (Herabudin , 2009: 137 ) . 
Based on the opinion of Asmani (2011:179), administrative management reveals actions that regulate or manage the entire job related to the administration. The steps in the process of administrative management, according to Henry Fayol are planning, organizing, directing, coordinating, controlling, and evaluating. Professional management emphasis on competence, a clear job description, evaluation, and dynamic.

Suharsaputra (2015:15) asserts,

"... management of university education can be interpreted as a management process which includes planning, organizing, implementing and monitoring the utilization of educational resources in order to carry out the roles and tasks of university Tridharma through strategy that was concerning with internal and external environment in achieving the goal with a leadership education context."

Thus the administrative activities within the education system called the governance or management. Educational activities will not be able to run well without the structure of the organization in charge of managing or managing various activities therein for the purpose achieving certain goals. That the quality of educational activities is very much influenced by good or not the governance or management of activities undertaken by the organization .

So far, cooperation projects handled by universities that focuses whether on academic or research has a complex procedure of arrangement and regulation. Moreover with the study sponsored by agencies or external organizations, usually carried out with the collaboration of the cooperation agreement that requires proper preparation and review by experienced grant administrator .

\section{Factors that Influence the Management of International Cooperation}

According to Torang (2014: 25 ), 
"Organizations consciously coordinated means of management and organization which is the entity (unity) social means that the unit was made up of people, or groups of people interacting. Thus, in many ways it can be said that the group is part of the organization."

From the opinion of some experts Torang ( 2014: 26 ) concluded that the organization has several variables: (1) the taxonomic organization, (2) organizational structure, (3) process in the organization , and (4) individuals within the organization.

According to the Consortium on Renewing Education (Murphy and Louis, ed. 1999:515) the institution has five forms of capital that needs to be managed for educational success :

1. Integrative capital, integrative capital is capital relating to the integration of four other capital to be utilized for the achievement of program / educational goals

2. Human capital, human capital is human resources capacity to use knowledge for the benefit of the process of education / learning .

3. Financial capital, financial capital is the funds needed to run and improve the educational process .

4. Social capital, social capital is a bond of trust and habits which describes the institution as a community

5. Political capital, political capital is owned basic legal authority to carry out the process of education/learning

From the theory of organizational variables and the five forms of organization capital by Murphy and Louis there are several factors that influence in the management of international cooperation can be identified as follows:

(1) Resources

a) human capital is human resources with the composition of the personnel responsible for the management of international cooperation. According to Thoha (2002:29) human is one of dimensions in a organization that is very 
important and becoming one of the factors supporting the organization;

b) financial capital is the entire budget, and facilities technology that owned and used in achieving goals.

(2) Authority, according Sujatmiko (2014:217) meaning of authority is legitimate power given to institutions in society that allows its officials to perform its functions.

(3) The organizational structure, in the opinion of Torang (2014, 82) that the organizational structure is out line within the organization scheme in which there are tasking from top placement until the determination of the tasks below.

(4) Next Torang argued that internal roles and responsibilities, and coordination systems and individual commitment to the doctrine and the program will affect the ability of the organization's resources to carry out the work programs are already established.

\section{RESEARCH METHOD}

The research was conducted at the University of March (UNS) involving units associated with managing a cooperative relationship that is the Legal and Administrative Cooperation, Integrated Service Unit International Service and implementation units in the faculties. The approach used is a qualitative approach, so that the data used is qualitative data obtained through methods and analysis of qualitative data. This is in line with the opinion of Bogdan and Taylor who called it a research procedure that produces descriptive data in the form of written or spoken words of people and behaviors that can be observed (Moleong, 1994: 3). Nonetheless quantitative data is still needed as supporting data for completeness of data analysis. 
This research tends to emphasize the natural setting (the state of nature) that exist. Researchers did not give a specific intervention against the phenomenon exists or can be referred to as a nonparticipant researchers. The research focus is on organizations that carry out the management of international cooperation at UNS, implementation units and administrator of cooperation, ranging from exploratory process until the follow-up of the cooperation. The research object is the management of International Cooperation, the process of the international cooperation between the UNS with other universities, businesses and or other parties.

Sources of data in this study are:

(1) Sources of primary data that informants were chosen deliberately in order to conduct the interview.

(2) Secondary data sources, places and events are a source of additional data is done by directly observing the activities of units related to the implementation of cooperation and the administrators of cooperation in carrying out their duties.

(3) Documents as other data sources that complement the main data, which are: constitution and regulation, cooperations data in UNS, budget and revenue data through the implementation of cooperation, the results of cooperation and utilization, as well as other various data that can be used as material analysis.

Data collection is by using the technique of recording or record from a variety of sources, either through interviews, observation and from documents on the unit / agency concerned. The samples informant done purposively, in order to obtain as much information as possible while maintaining the relevance of the research context.

In this study, the validity of the technique used is the technique of source triangulation is done by comparing the data findings with available data, to be more accurate. 


\section{RESULT AND DISCUSSION}

The principle of transparency requires the existence of mechanisms that facilitate public questions about the processes in governance. $\mathrm{Mr}$. TAM as head of the International Services Unit suggests communication between International Services Unit Service with various parties related to the international cooperation in the form of discussion and it is justified by Ms. LC, management staff of the Faculty of Economics and Business.

International Service Unit Sebelas Maret University also apply to the transparency through the opening means of communication for consultation and assistance in the preparation of the cooperation agreement with the various faculties, institutes, unit and other units in the hopes of implementing mutual openness between the central and delivery units. As informed by Mr. TAM coaching and consultation by the International Services Unit general though not disseminated to the faculty, institution, unit and other implementation unit is part of the facilitation of the International Services Unit. In addition, the readiness of the whole range International Service Unit for help assistance at the time of the MoU also be used by parties who wish to carry out international cooperation agreements under the umbrella of the university.

Implementation of cooperation or $\mathrm{MOU}$ in Sebelas Maret University can through two channels, namely on desk or through email correspondence and official letters. In the course of the two parties are on desk UNS and the partners meet each other through their respective representatives in a way UNS invites partner institutions to come or UNS invited to the outside. It is as stated by Mrs. FR staff of International Service Unit that transparency applied by International Service Unit is to invite stakeholders or parties with an interest in the field of cooperation that management units in the faculty, unit and institution in UNS . 
Efforts to increase transparency to the working partners, in the implementation of the MoU and MoA communications have been established by the International Services Unit as the representative of the UNS to the partners. As stated by Mr. TAM, communication between UNS with partner institutions related to the contents and clauses on cooperation to be implemented typically done through email and correspondence considering the location instistusi partner has a considerable distance and takes time, effort and funds which did little to each other face to face, then the communication media is considered quite effective.

In the framework of transparency and in order to make the spirit to initiate international cooperation, International Service Unit held the treaty release international cooperation that notification to stakeholders regarding MOUs have been implemented by the UNS with foreign parties that will be used as the basis for the faculty, institutions, technical service unit and other implementing units to initiate the activities of the technical and contractual agreement (MoA) with external parties is possible and according to the field. Hopefully, the academic faculty at UNS compelled to follow the programs of cooperation that already exist, and even expand to overseas institutions who are partners of the partner. Of course, when using an umbrella formally UNS faculties, institutes, technical service units and units field operators are obliged to contribute to the development of the UNS. In the interview Mr. TAM stated that the activities of the release of the cooperation agreement is possible to be done on a regular basis depending on the interests and needs of the university.

International Service Unit also open up opportunities for those who became a liaison or bring cooperation to UNS that can be realized for the development of international cooperation will be awarded through the mechanism of remuneration, as described by the Vice Rector of Planning and Cooperation, Mr. WM. 
Transparency with the release of the data UNS international cooperation through dissemination to all academic faculty and has also been uploaded online on the web International Service Unit. While the prominent activities that have been made include: a) look for opportunities and establish cooperation with universities abroad; b) seek opportunities and facilitate academicians who will pursue further studies, including by bringing international experts to give presentations on the opportunities of further studies, information and tips scholarships to study abroad, as well as tips on getting a Letter of Acceptance (e.g. from IDP Australian Education Center, The embassy of Australia, The Indonesian International Education Foundation, etc.); c) Facilitate and encourage productivity Educators UNS to write scientific papers in scientific journals of national and international accredited; d) Facilitate reward for Educators UNS who had the opportunity as a speaker / presenter in the international conference; e) Implementing a program of increased ratings UNS at international level through the Webometrics and Time Higher Education Supplement (THES).

The principle of transparency requires openness and standardization system is clear and easy to understand all the processes of governance. Standardization is no example in the form of policies, Standard Operating Procedures (SOP), rules, and guidelines. With the standardization is expected that no execution units cooperation to make policies, rules and procedures of their own in the management and implementation of international cooperation.

But until this study was conducted in Sebelas Maret University has been no policy, rules or SOP raw specifically load on the management of international cooperation, so that each implementation unit in the faculty, technical service units and agencies should be consulted often with the centers in this case the Legal Department and Administrative cooperation and International 
Service Unit in managing international cooperation . Of course it is deemed less effective, as stated by Mrs. Y, staff of Pascasarjana that no special unit that handles cooperation in courses so impressed not well coordinated and was necessary socialization of the procedure and the rules of cooperation in order to units under too familiar with the same workflow. The statement was confirmed by Mr. TAM that until now there is no standard SOP and similar things said by Mr. RM .

Standardize the other is about the rules, the Rector Decree No. 1 / H27 / KL / 2008 dated January 3, 2008 on Guidelines for the Cooperation of Sebelas Maret University considered less relevant to be used as guidelines for the implementation of cooperation now therefore drafted a new Rector Decree of the rules of implementation of cooperation more comprehensive and wide-ranging. The new Rector Decree will complement the rules and regulations that are not contained to the Rector Decree No. 1 2008. This is as stated by the Vice Rector for Planning and Cooperation Mr. WM in the Workshop on International Cooperation. Mr. DT as the expert staff Rector for Cooperation also said that the draft decree Rector newly already mentioned cooperation is an activity that is mutually beneficial and provide benefits to the eskternal both domestically and abroad as outlined in the form of $\mathrm{MoU}$ and MoA, and already mentioned this regulation will involve domestic and abroad. But the rules in it there are no specific rules governing foreign cooperation.

The principle of transparency requires reporting and information dissemination mechanism of action of a public official in irregularities in the activities of governance. The absence of system maintenance, system monitoring and evaluation of the cooperation led to the principle of transparency seem to be heavy into effect because a lot of the MoU and MoA are not even listed in the section and other units even in study program itself. Poor transparency in oversight led to some appalling conditions: 
- The cooperation or MOU that sleep because there is no follow-up in the long term. MoU only be written data without any action so as to be in vain but to get it with exertion, thinking and no small amount of it had been expressed by Mr. SH, Vice Dean of the Faculty of Agriculture UNS.

- Mr. WM workshop Socialization of International Cooperation procedure suggests, when a cooperation agreement or $\mathrm{MoU}$ were not recorded while the umbrella is the UNS there is a problem then it will drag the name of the institution UNS while the institution did not have any evidence for the defense.

Mr. TAM explain to overcome the problems of the SOP and the rules, then the steps to be taken in the management of cooperation in the UNS is to:

- To disseminate the cooperation procedure abroad is accompanied by an explanation of important documents that accompany it. Socialization is done both internally and externally through various media and activities. Dissemination activities will be very important held annually in light of the pace of development of higher education significantly.

- Currently the UNS in this case the International Service Unit is building a system for maintenance $\mathrm{MoU}$ which in this system will be well recorded data MoU and MoA owned by UNS, units associated therewith and any person who is responsible. So expect later UNS able to capture and explore every opportunity of any cooperation undertaken resulting in outputs and outcomes that can be used as much as possible for the development of institutions.

In an organization the main components driving the organization is functioning, personnel / individual and factors of physical facilities. In the case of divide and classify the work as an initial activity of organizing the University Presented by Head of International Service Unit, Mr. TAM Sebelas Maret University has 
been carrying out the distribution and management of job grouping of international cooperation in accordance with the duties and functions of the principal.

The main activity in the management of international cooperation in the Sebelas Maret University, among others: a) Implement the initiation and drafting letters of agreement, b) a review of the agreement, c) approval and validation of Chairman, d) discussion of the final draft by the partner institutions, and e) the signing of a letter of agreement accompanied by one witness from each party involved. Head of International Service Unit Mr. TAM explains that International Service Unit only works until the realm of the document signer cooperation agreements or MOU and never reached the MoA which incidentally is the implementation of the agreements and contracts. This is because the International Service Unit does not have the academic activities such as faculty and other technical units. But monitoring is still being done by the International Service Unit every implementation of the MoA in faculties and other units.

In organizing the distribution and grouping has no clear job in order to avoid abuse. But it is not supported by the state is still the number of units in the faculty, technical service units and agencies that have not been able to understand the duties and functions of management work well together because of lack of communication and coordination with the management of cooperation at the university level. Presented by Mrs. YP of the Faculty of Education that the draft MoU to be reviewed often less well and incomplete contents and does not put the basic principles of cooperation therein.

Presented by Mr. TAM, due to a lack of understanding of the duties and functions as a manager and executor of the cooperation existing units that have a MoU but did not follow through with activities, and some units that do not have a MoU but piggybacking on another unit owner MoU. It's certainly not a great impact because implementation unit does not seem professional and non 
synchronization $\mathrm{MoU}$ with activities in the field of implementing units. In the end when the MoU / MoA has expired expect problems to extend.

Awareness to initiate cooperation, report and share it for the sake of the university was still low. This is evident from the data at least the cooperation that can generate revenue generating mainly generated by the educators who have completed studies abroad. Many of them are still intense for communication with almamater even some of the many educators who have produced studies and still continue after completion of studies.

As expressed by Mr. WM, during this time the University has opened up greater opportunities and easier for educators who will carry out collaborative research abroad with an umbrella UNS without having to go through the MoU beforehand because it is expected to be a way to increase the initiation of further cooperation. But it is unfortunate given the ease that has not been accompanied by the awareness to take advantage of the research collaboration for the development of the university.

Almost same condition occurs in the accountability of financial reporting. The lack of initiative reporting of Person in Charge (PIC) activities of cooperation on budget accountability contracts of cooperation and the absence of standard mechanism for reporting income and expenses led to data on the number of revenue generating in the Sebelas Maret University just as the written record alone, but in real terms equitable distribution of the results of the cooperation is still lacking. As disclosed Mr. TAM, the lack of standard SOP for the cooperation process both domestically and abroad caused no person who is responsible for the follow up of the $\mathrm{MoU}$. So it is still dependent on the persons implementing the MoU want to report.

There are no standard financial accountability mechanisms in the implementation units in faculties, institutes and technical service unit 
of the amount of usage of budget and revenue sources university of international cooperation programs. It seems that their attitude is still very strong personal privacy and lack of attitude sense of belonging to the university.

Information obtained from Mrs. EV, Fund Corporate Manager Finance Department said that the disbursement procedure is very easy and the absence of an accountability system monitoring cooperation in the Finance Section UNS raises the possibility for the dishonesty of implementing cooperation.

The accountability of budget planning is still visible irregularities, for example filing TOR and budget disbursement cooperation implies still vulnerable and less strict in selecting budget TOR, as revealed by Mr. RM, that is often encountered in the field TOR submitted without any prior MOU or LOI. Though bagain Legal and Administrative Cooperation already making a circular that the document can not be one-sided cooperation was signed by the head of the unit of work, all must pass to receive a validation cooperation administrator WR IV.

Information from Mr. W as Vice Dean of the Faculty of Cultural Sciences indicates that during this activity more cooperation is the personal and scattered in various faculties, institutes, technical service units and units within the UNS especially with still not yet well established SOP, reporting, monitoring and evaluation cause still fertile cooperation practices through cooperation that is not the legality of UNS as a provider of legal protection cooperation.

Sebelas Maret University should always prioritize conformity in the management of the college according to the legislation in force and the principles of healthy and quality institutions. However establish governance systems of international cooperation principled Good University Governance is not as easy as turning the palm of the hand. Problems expressed by Mr. RM that the lack of clarity of 
responsibility and authority of sections / units into the entrance of cooperation because until now there are three entrances, cooperation is still active all three, This part of the Legal and Administrative Cooperation, taskforce Relations and Cooperation in International Service and Business Unit Management Agency (BPU) .

Clarity of responsibility and authority is also still questionable in the rules of the Organization and Governance UNS new: smelting Office of Public Relations and Cooperation which has a wide scope (domestic and foreign) into the International Service Unit which has a scope is narrower (only overseas only). It refers to the Minister of Education and Culture of the Republic of Indonesia Number 82 of 2014 on the Organization and Work Procedure of Sebelas Maret University where it is stated in Article 130 that the International Service Unit has the task of carrying out the affairs of the publication, reporting activities UNS, public relations, as well as the facilitation of international cooperation, student services, teachers and foreign, and international promotion UNS. While on the Rector Decree of Sebelas Maret University Number: 649 / J.27 / KL / 2004 on the Establishment of the Office of Public Relations and Cooperation of Sebelas Maret University, Office of Public Relations and Cooperation UNS an operation unit that is responsible for coordinating and administering or running activity on the level of cooperation University conducting a builder under the Vice Rector and responsible to the Rector. Here it is clear that the Office of Public Relations and Cooperation has a scope broader task of International Service Unit not only in the international sphere, but also includes a wide range of cooperative relationships with outside parties both inside and outside the country, so it could be said to be odd if these rules are applied in the management of cooperation at Sebelas Maret University.

The pattern of coordination and delegation of authority are still confusing for their organization and the new governance, it is seen 
from the same role held by two units of implementing cooperation which the Public Relations Office as part of the International Service Unit is still dealing with the implementation of administrating cooperation should become the region of Office of Legal and Administrative Cooperation. As expressed by Mr. RM, according to OTK 2014 UNS clear that the Office of Legal and Administrative cooperation has a role in the implementation and administration cooperation at home and abroad .

Unclear pattern of coordination and delegation of authority between the three units can also be a problem when the units in faculties, institutes and technical service unit you want to consult or ask the flow of international MoU implementation in UNS expressed by Mr. TAM .

The impact of the ambiguous application of the rules to these structural is a conflict of functions between the taskforce Relations and Cooperation International Service Unit of the Office of Legal and Administrative Cooperation in terms of administrating cooperation at home and abroad led to the dualism in faculties, institutes and technical service units to do communication and coordination related to the management of the cooperation. From several questions to the management unit of cooperation in all faculties at the UNS about the unit Which often coordinated (International Service Unit, a taskforce Relations and Cooperation, and the Office of Legal and Administrative Cooperation) turned out to be a manager in the faculty say most often coordinate and communicate the International Service Unit 7 people, with a taskforce Relations and Cooperation as many as 6 people and with the Office of Legal and Administrative Cooperation as many as five people.

Correspondence between what is done to mobilize human resources with the applicable rules and regulations it is not yet meet the responsibility aspect. This can be seen from a variety of rules that 
86 should be adhered to by the academic faculty in encouraging the development of human resources are still many who are not adhered to and there are a lot of deskresi policies that ultimately favor of the offenders. In this case unquestionable commitment to the responsibility and authority according to the rules that have been determined and agreed upon.

One of the offenses relating to international cooperation is the lack of rules regarding educators who have completed advanced study abroad have to go back to university to carry out its obligations as educators and using science that has been gained for the development of the university. This rule contained in the Regulation of the Minister of Education and Culture No. 48 of 2008 where educators who have completed advanced study abroad are required to return to the college of origin and the teaching of as many as $2 n$ ( $n$ is the length of time required in question for further study). However, the implementation in the field educators who have completed advanced study abroad there is a direct proceed to the stage of Post Doctoral citing the opportunity to work and while there is still not active as educators in universities and even after Post Doctoral there is no return to the institution origin.

University course want all educators had to develop themselves and are expected to bring science and the positive results that can be used to develop UNS certainly approve this step and in the end there deskresi-deskresi policy pursued by the leadership of the various positive regard for the development of UNS, Here, in the end the size of responsibility in the management policy of human resources (HR) are not met.

Until today in the Sebelas Maret University has been no mechanism to the imposition of sanctions and penalties personal or institution which violates the international cooperation. In fact, if examined further management of this international cooperation is an area which is very risky to drift. So an awful lot going on pem'biar'an 
case of violation of regulation or rule, as a result of control and monitor function is not running. Mr. WM said, for now there is no strong law to impose sanctions on those who violate the cooperation.

In the case of cooperative joint research, for example, there are some educators who, after completion of further studies abroad and then they went on research which is owned by the University where his studies and ultimately not willing to return to serve the UNS is due to feel comfortable living abroad though salaries and allowances UNS remains intact from acceptable, once again responsibility SDM also not met in the oversight function.

UNS expects that with the return of the educators of advanced study abroad can be brought home for research collaboration can be transmitted to other academic faculty for the development of the university. But the facts show data from the Personnel Section Sebelas Maret University between 2000 and 2015 there were approximately eight (8) persons educators civil servant status, which is carrying out further studies abroad who then did not return to the home institution for various reasons. (Source: Data Division Officer and Cooperation Section 2015)

Again no penalty expressly stating that UNS is entitled to take back the assets that have been given to personnel who violate the rules and legal sanctions to him because there are no legal provisions are certainly concerning sanctions to violators.

For a system of accountability and budget reporting cooperation until penilitian do not yet have a Standard Operating Procedure (SOP) that is due to the budget disbursement working only through the Fund's account Rector where funds through this route can not be held accountable for its use as just passing through and recorded only. So on this funding cut for university fee and fee-carrier cooperation projects and then immediately taken by the relevant implementing units. 
When viewed from the financial management policy with the increasing number of collaborative activities that generate revenue generating primarily for financial management should UNS international cooperation is not as simple as this. This was stated by Mr. DK , finance staff who handle the Operational Fund that the budget management is very risky cooperation occurs diversion and abuse, as it involves huge funds it would require more stringent mechanisms to ensure accountability.

The first factor is the human resources (HR) where the Sebelas Maret University has educators, staff and students who have been carrying out overseas activities in the framework of further study, initiation or organization of cooperation (MoU), joint research, following the international conference, execute sit in lecture, lecturer exchange, exchange students, as well as other academic support activities .

Looking at the number of human resources UNS foreign conducting international cooperation opportunities that can be extracted from human resources to implement these activities abroad and this will continue throughout the year, even increasing in line with the acceleration of the internationalization program in UNS. The existence of substantial funds to finance the departure abroad should be accompanied by significant contributions and results. But it all depends on the commitment and loyalty of each personal, because not all teachers have the ability and willingness to carry the name of the institution of origin and place itself as a marketer to promote to outsiders about UNS excellence through the forum.

Aside from being a bridge of international cooperation, with the number of teachers qualified Doctor Specialist 414 people and as many as 40 people can provide imaging and image building that is good for UNS. The number of experts and specialists of various fields of science comes from educators qualified Doctor is a human resources should really be developed and used well as experts and 
specialists particular field is still very rare in this country and is needed by many parties, both public and private. Therefore, Mr. RM expressed the need for identification of intellectual property such as HR expert, copyrighted works, discoveries and innovations that are owned by the UNS to be used as guidance profile to lure outsiders to cooperate.

The number of qualified educational personnel Master, Bachelor and Vocational Education is a human who rated capable of handling the administration as well as assisting in the management of international cooperation. With the number of qualified human resources is as much as 312 people Sebelas Maret University seems to have enough resources to be used for the acceleration of internationalization, but it must be accompanied by the development of human resource capacity and skills through workshops, seminars and short courses management cooperation at home and abroad.

$\mathrm{Mr}$. RM also provides that the assessment of human resources in the Sebelas Maret University still have the insight and motivation that need to be addressed and improved overall. To be able to empower and harness human resources are so abundant and highly qualified is of course necessary to manage the cold hands become engines of acceleration UNS towards world-class universities. Therefore we need a human asset identification and data collection on intellectual property to be held marketing superior products.

The second factor is a factor that affects the authority. Vice Rector of Planning and Cooperation, International Service Unit, the Legal and Administrative Cooperation, and the coordinator of the faculty level cooperation, the level of institutions and technical service units have individual authority in the management of international cooperation in the Sebelas Maret University.

As the central figure in the Vice Rector of Planning and Cooperation in the management of international cooperation to authorize directly to the Legal and Administrative Cooperation 
(HAK) to carry out administrative cooperation at home and abroad, and authorize the International Service Unit to conduct the affairs of publication, reporting UNS activities, public relations, as well as the facilitation of international cooperation, student services, teachers and foreign, and international promotion UNS.

Mr. TAM revealed the role of the International Service Unit is the facilitation of international cooperation is to help the units that will implement the cooperation agreements ranging from the initiation stage of international cooperation through the signing of a cooperation agreement. International Service Unit and the Legal and Administrative Cooperation is a manager at the university level in the respective faculties, institutes and technical service units are administrative units that have the authority dealing with cooperation in their respective sections.

From the above explanation can be seen that there is no clear authority carried by each management unit cooperation so that they can carry out the role that correspond with the position and authority of each well. Stakeholders were able to perform the role according to the task and function will be very supportive in the management of international cooperation in the Sebelas Maret University.

The third factor is the organizational structure. The changing pattern of coordination and delegation due to changes in the Organization and Governance (OTK) Sebelas Maret University's new in accordance with the Regulation of the Minister of Education and Culture of the Republic of Indonesia Number 82 of 2014 on the Organization and Work Procedure of Sebelas Maret University also fundamentally changed the organizational structure and pattern coordination in the management of international cooperation in the Sebelas Maret University. An error in the preparation of the new OTK as an element of intent or in fact should be enforced because it has an element binding rules. Integration of Office of Public Relations and Cooperation which acts as administrator of 
cooperation at home and abroad into the taskforce International Service Unit that handles the facilitation of international cooperation carries the implication that the International Service Unit is now not only facilitates international cooperation, but also cooperation in the country. As for the administration, recording and archiving of cooperation in the country have been handled by the Legal and Administrative Cooperation.

Structural conditions ornganisasi this must be fixed so that the future will not bring negative impacts worse given to support an organization's structure is the most important variables which form the organizational structure will contribute to determine the division of duties, accountability mechanisms, coordination mechanisms, the delegation of authority and patterns of interaction, where current organizational structure is not good then the organization will not be able to walk reach the desired goal.

The fourth factor is the coordination system. Conditions organizational governance structure of cooperation of Sebelas Maret University today is not the ideal conditions that are expected to accelerate the UNS governance into Good University Governance. International Service Unit, Office Cooperation Section and the Office of Public Relations and Cooperation should be in parallel lines that are on the roof where coordination and communication can be maintained its sustainability. It is, as mentioned Mr. TAM above that the existence of two different roof in the management of cooperation, of which one is under the Bureau of Academic and Administrative Cooperation and the other is located directly under the coordination of Vice Rector of Planning and Cooperation. Although the Vice-Rector for Planning and Cooperation has the authority to give orders to the Head of Legal and Administrative Cooperation but the structural organization of the Bureau of Academic and Administrative Cooperation is not under the field of Planning and Cooperation. These conditions also impact the 
92 differences in the pattern of coordination between the central and the units below that in the faculties, institutes and technical service unit, there are coordinating with the International Service Unit, a taskforce Relations and Cooperation and the Office of Legal and Administrative Cooperation.

Therefore, it is necessary to develop Standard Operating Procedure (SOP) that is clear and regulation of the management of international cooperation raw advance, and can be socialized to equate the perception and direction, to be able to become the foundation of the driving acceleration of the internationalization of the Sebelas Maret University to the university superior world 2030.

\section{CONCLUSION}

1. Regarding to the management of international cooperation, the role of planning hold function is crucial because at this stage will be held the determination of areas of cooperation that will be initiated which followed the different stages of the $\mathrm{MoU}$ with the parties cooperate, the revised draft $\mathrm{MoU}$, agreed on a draft $\mathrm{MoU}$ to be signed by deputy both parties and signatories to the $\mathrm{MoU}$ itself. Therefore, the instrument should be drafted regulations, policies and SOP standard so that no longer occur differences in the implementation of the cooperation procedure both $\mathrm{MoU}$ and MoA.

2. To meet the accountability in terms of budget management cooperation, must be drafted standard operating procedures concerning disbursement system budgets and tougher accountability system because during the Sebelas Maret University have yet to implement the monitoring of the use of budgetary cooperation. Hopefully, through clear and strict procedures will be visible where the direction of flow of cooperation funds are used 
so that the utilization of the funds can be directed to the interests of the development of the university.

3. Related to the lack of marketing solutions featured product that can be used to attract outside parties to cooperate with the Sebelas Maret University, need to be made the mapping of a superior product that is owned by UNS like profiling expertise, innovations and patent rights as well as the work of educators UNS students. With the mapping of superior products is expected as capital UNS marketing opportunities in the widest possible cooperation.

\section{REFERENCES}

Agus Dwiyanto. (2006). Mewujudkan Good Governance Melayani Publik. Yogyakarta: Gadjah Mada University

Aseri, H. Akh. Fauzi. (2015). Mendaki Sukses Tata-Kelola Perguruan Tinggi. http://www.iain-antasari.ac.id. Accessed 10 February 2016.

Asmani, Jamal Ma'mur. (2011). Tips Praktis Membangun dan Mengolah Administrasi Sekolah. Yogjakarta: DIVA Press.

Bowo dan Andy. (2007). Pengertian Kerjasama. http://lompoulu.blogspot.com. Accessed 04 January 2016

Breen, Helen; Nerilee, Hing. (2001). Research: Improving Competitiveness Through Cooperation: Assessing the Benefits of Cooperative Education Partnership in Gaming Management. UNLV Gaming Research \& Review Journal, vol. 6, no. 1, hlm 57-72.

Dwiyanto, Agus. (2011). Mengembalikan Kepercayaan Publik Melalui Reformasi Birokrasi. Jakarta: Gramedia Pustaka Utama.

Hendarman. (2009). Peran dan Kebijakan Direktorat Jenderal Pendidikan Tinggi dalam Mendukung Perguruan Tinggi Menjadi World Class University. Seminar Potensi Universitas Islam Indonesia (UII) Menjadi World Class University Yogyakarta: 26 Juni 2009.

Herabudin. (2009). Administrasi dan Supervisi Pendidikan. Bandung: CV Pustaka Setia.

Keban; Soekanto, S. (2007). Sosiologi Suatu Pengantar, Edisi 4. Jakarta: PT. Raja Grafindo Persada.

Krina P, Loina Lalolo. (2003). Indikator \& Alat Ukur Prinsip Akuntabilitas, Transparansi \& Partisipasi. Jakarta: Sekretariat Good Public Governance Badan Perencanaan Pembangunan Nasional.

Mardiasmo. (2002). Akuntansi Sektor Publik. Yogyakarta: Penerbit Andi. 
Moleong, Lexy J. (1994). Metodologi Penelitian Kualitatif. Bandung: PT. Remaja Rosdakarya.

Muhi, Ali Hanapiah. (2010). Implementasi Nilai-Nilai Good Governance di Perguruan Tinggi. http://alimuhi.staff.ipdn.ac.id. Accessed 01 December 2015.

Nayono, Satoto E. (2012). Kerjasama Internasional Perguruan Tinggi: Pengalaman di Universitas Negeri Yogyakarta. Workshop Inisiasi Kerjasama dengan Perguruan Tinggi Asing Institut Seni Indonesia Yogyakarta: 13 Desember 2012.

Pamudji S. (1985). Kerjasama Antar Daerah. Jakarta: Bina Aksara.

Peraturan Menteri Pendidikan dan Kebudayaan Nomor: 14 tahun 2014 tentang Kerjasama Pendidikan Tinggi

Purbani, Widyastuti. (2009). Menuju World Class University. Yogyakarta: Universitas Negeri Yogyakarta.

Rasul, Syahrudin. (2003). Pengintegrasian Sistem Akuntabilitas Kinerja dan Anggaran dalam Perspektif UU NO. 17/2003 Tentang Keuangan Negara. Jakarta: PNRI.

S. Gallichio, Vincent. (2007). Administration of an Innovative Program of International Cooperation: Success Across the Pond. The Journal of Research Administration, vol. XXXVIII, hlm. 203-210.

Suharsaputra, Uhar. (2015). Manajemen Pendidikan Perguruan Tinggi. Bandung: Refika Aditama.

Surat Keputusan Rektor Nomor: 1/H27/KL/2008 Tanggal 3 Januari 2008 tentang Pedoman Kerjasama Universitas Sebelas M aret.

Undang-undang Nomor 12 Tahun 2012 tentang Pendidikan Tinggi 